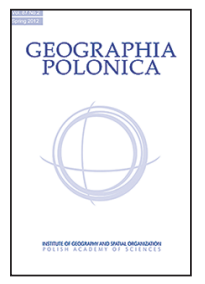

\title{
COMPARISON OF TWO METHODS OF WARM AND COLD WAVE IDENTIFICATION BASED ON THE EXAMPLE OF SELECTED CITIES OF THE MODERATE AND COLD ZONE
}

\section{Agnieszka Krzyżewska}

Maria Curie-Skłodowska University

Faculty of Earth Sciences and Spatial Management

al. Kraśnicka 2 cd, 20-718 Lublin: Poland

e-mail: krzyzewska.agnieszka@gmail.com

\begin{abstract}
The following paper compares two methods for identifying warm and cold waves, representing different methodological approaches: the 'relative' approach, i.e. wave identification based on the standard deviation, and the 'arbitrary' approach, i.e. wave identification based on a specified thermal threshold. The 1981-2010 comparison is based on data from eleven selected large cities of the world. The cities are located in zones $\mathrm{C}$ and $\mathrm{D}$ according to the Köppen climatic classification. More of the thermal waves and their parameters (number of waves, number of days in waves, their durations, and number of warm and cold days) were determined by means of the relative method than the arbitrary method. Cold waves and cold days distinguished by means of both methods, predominated over warm days and warm waves in a given period, whereas the number and duration of warm waves and warm days increased.
\end{abstract}

\section{Key words}

warm and cold wave $\cdot$ large cities of the world $\cdot$ thermal wave identification methods

\section{Introduction}

Warm and cold waves have no precise definition - they are broader concepts of meteorological phenomena than heat waves in summer and frost waves in winter (for example - warm waves can be understood as a spell of several warmer days during winter time). The available meteorological and climatological dictionaries (e.g. WMO 1992; Niedżwiedź
2003) provide quite general explanations of terms related to thermal waves. For example, a dictionary description of a warm wave is "a substantial increase in temperature with duration from several days to several weeks", and a cold wave as "a substantial cooling of air or inflow of very cold air". These definitions do not permit the determination of an unequivocal method of identification of thermal waves. Therefore, the scientific literature 
includes a number of works where the authors developed their own methods of studying the phenomenon of warm and cold waves (e.g. Morawska-Horawska 1991) or heat waves (Robinson 2001; Koppe et al. 2004; Kuchcik 2006; Matzarakis \& Nastos 2010).

The methodological approaches to the identification of thermal waves differ substantially. Thermal waves are usually identified based on an exceeding of the mean multiannual daily temperature or extreme temperature by the mean daily temperature, using a standard deviation or part of the standard deviation (Morawska-Horawska 1991; Mager \& Kuźnicka-Błaszczyńska 1993; Miętus \& Filipiak 2001; Wibig et al. 2009a,b). Some papers refer to thresholds established by percentiles (Degirmendžić 1999; Kozłowska-Szczęsna et al. 2004). According to other papers, a thermal wave is identified when the current temperature exceeds the multiannual value e.g. by $4^{\circ} \mathrm{C}$ (Balafoutis \& Arseni-Papadimitriou 2002). A completely different approach is presented by M. StopaBoryczka et al. (2011), where thermal waves are understood as periods with decreased or increased mean multiannual daily air temperature in relation to the mean annual temperature sinusoid.

The objective of this paper is to compare the two methods (the arbitrary method and the relative method) used to identify warm and cold waves, representing two different methodological approaches, applying relative
(Mager \& Kuźnicka-Błaszczyńska 1993) and arbitrary thresholds (Balafoutis \& Arseni-Papadimitriou 2002) to determine the advantages and limitations of those approaches.

\section{Study material}

The paper is based on data provided by the National Climatic Data Center (NCDC 2014) from the complimentary GSoD data base (Global Summary of the Day) for 11 large cities (Tabs. 1, 2) in the world. The data are the mean daily air temperature, maximum daily air temperature, and minimum daily air temperature.

The cities are located in zones $C$ and $\mathrm{D}$ according to the classification by KöppenGeiger (Kottek et al. 2006). In this classification, there are 5 climate zones distinguished. The zones are based on temperature and precipitation ( $\mathrm{A}$ - equatorial, B - arid, C - warm temperature, $D$ - snow, $E$ - polar). The comparison excludes zones $A$ and $B$ due to lower thermal variability resulting in excessively high (in the case of the relative method) and excessively low (in the case of the arbitrary method) number of waves. Due to the lack of large cities, zone E was also excluded.

The comparative analysis of thermal waves covered those airport stations performing 24 measurements per day. Data from the aforementioned data base, and particularly temperature data, have already been used in similar analyses for: the territory of Poland

Table 1. Location of stations in the zone of moderately warm climates, and data gaps in the 1981-2010 period

\begin{tabular}{|c|c|l|c|c|c|c|c|}
\hline $\begin{array}{c}\text { Climate } \\
\text { zone }\end{array}$ & Station No. & \multicolumn{1}{|c|}{ Station name } & Country & Latitude & Longitude & $\begin{array}{c}\text { Altitude } \\
{[\mathrm{m} \text { a.s.I.] }}\end{array}$ & $\begin{array}{c}\text { Data gaps } \\
{[\text { days] }}\end{array}$ \\
\hline Cfa & 476710 & Tokyo Intl Airport & JP & $35^{\circ} 33^{\prime} \mathrm{N}$ & $139^{\circ} 47^{\prime} \mathrm{E}$ & 8 & 3 \\
$\mathrm{Cfa}$ & 583670 & Shanghai-Hongqiao & $\mathrm{CN}$ & $31^{\circ} 10^{\prime} \mathrm{N}$ & $121^{\circ} 26^{\prime} \mathrm{E}$ & 7 & 43 \\
$\mathrm{Cfa}$ & 744860 & New York-JFK Airport & US & $40^{\circ} 39^{\prime} \mathrm{N}$ & $73^{\circ} 47^{\prime} \mathrm{W}$ & 7 & 2 \\
$\mathrm{Cfb}$ & 37720 & London-Heathrow & UK & $51^{\circ} 29^{\prime} \mathrm{N}$ & $0^{\circ} 27^{\prime} \mathrm{W}$ & 24 & 6 \\
$\mathrm{Cfb}$ & 71490 & Paris-Orly & FR & $48^{\circ} 44^{\prime} \mathrm{N}$ & $2^{\circ} 24^{\prime} \mathrm{E}$ & 96 & 42 \\
$\mathrm{Cfb}$ & 947670 & Sydney Intl Airport & AU & $33^{\circ} 57^{\prime} \mathrm{S}$ & $151^{\circ} 11^{\prime} \mathrm{E}$ & 3 & 20 \\
$\mathrm{Csa}$ & 170600 & Istanbul-Ataturk Ab & TR & $40^{\circ} 58^{\prime} \mathrm{N}$ & $28^{\circ} 49^{\prime} \mathrm{E}$ & 37 & 4 \\
$\mathrm{Csb}$ & 688160 & Cape Town-Df Malan & ZA & $33^{\circ} 59^{\prime} \mathrm{S}$ & $18^{\circ} 36^{\prime} \mathrm{E}$ & 42 & 14 \\
\hline
\end{tabular}


Table 2. Location of stations in the zone of subnivean climates and data gaps in the 1981-2010 period

\begin{tabular}{|c|c|l|c|c|c|c|c|}
\hline $\begin{array}{c}\text { Climate } \\
\text { zone }\end{array}$ & $\begin{array}{c}\text { Station } \\
\text { No. }\end{array}$ & \multicolumn{1}{|c|}{ Station name } & Country & Latitude & Longitude & $\begin{array}{c}\text { Altitude } \\
{[m \text { a.s.I.] }}\end{array}$ & $\begin{array}{c}\text { Data gaps } \\
\text { [days] }\end{array}$ \\
\hline Dfb & 24640 & Stockholm-Bromma & SE & $59^{\circ} 21^{\prime} \mathrm{N}$ & $17^{\circ} 57^{\prime} \mathrm{E}$ & 11 & 26 \\
Dfb & 712650 & Toronto II Arpt Aut & CA & $43^{\circ} 38^{\prime} \mathrm{N}$ & $79^{\circ} 24^{\prime} \mathrm{W}$ & 77 & 17 \\
Dfb & 275155 & Moscow-Sheremet'ye & RU & $55^{\circ} 59^{\prime} \mathrm{N}$ & $37^{\circ} 30^{\prime} \mathrm{E}$ & 190 & 22 \\
\hline
\end{tabular}

(Krzyżewska \& Wereski 2011), Europe (Kossowska-Cezak \& Twardosz 2012a,b), selected cities in the world (Krzyżewska 2010), or changes in the temperature in the Arctic (Matthes et al. 2009). They were also used to study the rate of global warming (Viola et al. 2010), or e.g. the effect of climate changes on wheat crops (Özdoğan 2011), as well as for integration with other climatological (Yang et al. 2010) or satellite data bases (Nghiem et al. 2009).

\section{Methods}

The first method was developed by Mager and Kuźnicka-Błaszczyńska (1993), and applied in the climate study of the city of Poznań, Poland for the 1911-1990 time period. The paper defines a warm or cold wave as a period of at least 2 days with the mean daily temperature differing from the mean multiannual temperature for a given day of the year by half the standard deviation:

$$
\begin{aligned}
& x_{i}>x_{\text {avg }}+0.5 \delta \text { (warm wave) } \\
& x_{i}<x_{\text {avg }}-0.5 \delta \text { (cold wave) }
\end{aligned}
$$

where:

$\mathrm{x}_{\text {avg }}$ - mean multiannual air temperature for a given day of the year

$\delta$ - standard deviation of the mean daily air temperature calculated for the same day of the year

The second method was developed by the Greek scholars C. Balafoutis and A. ArseniPapadimitriou (2002). It was applied for research concerning the southern Balkans. A very warm spell was defined as a period of three or more consecutive days in which the maximum temperature is higher than the mean multiannual maximum temperature by $4.0^{\circ} \mathrm{C}$ or more. A very cold spell is a period of three or more consecutive days in which the maximum temperature is lower than the mean multiannual maximum temperature by $4.0^{\circ} \mathrm{C}$ or more:

$$
\begin{aligned}
& x_{\text {max }}>x_{\text {avg max }}+4^{\circ} \mathrm{C}(\text { warm wave }) \\
& x_{\text {max }}<x_{\text {avg max }}-4^{\circ} \mathrm{C}(\text { cold wave })
\end{aligned}
$$

where:

$\mathrm{x}_{\text {avg max }}$ - mean multiannual maximum air temperature for a given day of the year

$\mathrm{x}_{\max }$ - maximum daily air temperature

For comparative purposes, this paper adopts three days as the minimum wave duration. The comparison considers parameters such as:

- number of waves in the multiannual period studied (1981-2010), and mean annual number of waves,

- number of days in waves in the multiannual period studied (1981-2010), and mean annual number of days in waves,

- number of days (both in waves and single) meeting the criteria of the method in the multiannual period studied (1981-2010), and mean annual number of days meeting such criteria,

- mean wave duration.

In terms of duration, warm and cold waves were classified into the following groups: very short (3-5 days), short (6-10 days), moderately long (11-20 days), long (21-30 days), and very long (>30 days). Apart from the total number of warm waves, the duration of the warm waves is also of key importance (Kyselý 2010). The duration is substantially varied. Therefore, the following analysis also considers the number of days included in warm and cold waves, and the number of days meeting 
the criteria of a given method (i.e. in addition to days in a wave, also single or double days). So that the paper is more coherent and readable, those days meeting the criteria of a cold wave, from now on will be referred to as cold days, and those meeting the criteria of a warm wave - warm days.

\section{Results}

\section{The relative method applying the standard deviation - zone C}

Cold waves. In zone $C$, the mean annual number of cold waves varied from approximately 14 in Istanbul to approximately 17 in Sydney (Tab. 3), and their mean duration varied from 4.6 to 6.6 days. Cold waves occurred in all of the study years. The lowest number of cold waves was recorded in Istanbul in 1999 (5 waves), and the highest in Tokyo INTL in 1986 (29 waves). The number of cold waves in the study period decreased. Based on the annual mean, the waves occurred somewhat more frequently in the warm half-year than in the cold halfyear. The lowest number of days in waves was observed in Istanbul (1999, 25 days), and the highest in Tokyo in 1984 (188 days).

The mean annual number of days in waves in the zone was considerably varied, and ranged from 73 to 98 , and the number of cold days - from 112 to 120 (Tab. 3). Among the stations studied, extremely long cold waves only occurred in Istanbul and London ( 3 waves and 1 wave, respectively).

Warm waves. The mean annual number of warm waves varied from approximately 13 in Cape Town to approximately 16 in London (Tab. 3). The mean duration of the waves was from 4.3 to 6.1 days. The warm waves were usually recorded in the cold ${ }^{1}$ half-year and the most seldom - in the warm² half-year. The waves occurred every year from 1981

\footnotetext{
1 Cold half-year is understood in climatology as the period from October till March (Niedźwiedź 2003).

2 Warm half-year is understood in climatology as the period from April till September (Niedźwiedź 2003).
}

to 2010 , and the number of waves has been increasing. The lowest number of waves was recorded in 1986 in Tokyo (3 waves), and the highest in 2009 in Sydney (27 waves). The lowest number of days in waves occurred in 1986 at the Tokyo INTL station (10 days), and the highest in 2010 in Istanbul (189 days).

The mean number of days in warm waves was largely varied in the zone, and ranged from 55 to 88 days per year, and the number of warm days - from 99 to 115 days per year (Tab. 3). In the study years, there were 3 extremely long warm waves which occurred only in Istanbul.

Wave duration. In this zone, large disproportions are observed between the number of warm and cold waves per year, with a predomination of cold waves. On the average, very short cold waves occurred from 8 times in Istanbul to 13 times in Sydney. In all of the cities, approximately 4 short waves occurred, as well as one to two moderately long waves. The remaining waves were observed less than once per year. Very short warm waves occurred from 8 times in Istanbul to 11.5 times in Sydney, on the average. Short waves were recorded from 2 to 4 times per year, moderate waves once per year, on the average, and the remaining ones more seldom. Only in London and Istanbul were the predomination of warm waves over cold waves observed in the case of short waves. At the remaining stations, cold waves were predominant.

\section{The arbitrary method used in applying a threshold of $4^{\circ} \mathrm{C}$ - zone $\mathrm{C}$}

Cold waves. In zone $C$, the mean annual number of cold waves varied from approximately 3 in Sydney to approximately 7 in Paris. Their average duration was from 3.5 to 5.0 days. Cold waves did not occur every year at each of the study stations. The highest number of waves was recorded at the New York-JFK station in 1996 (19 waves), and the highest number of days in waves occurred at the Paris-Orly station in 1987 (104 days). During the year, at the majority of stations, 
the waves were the most frequent in winter, and the least frequent in summer. The mean annual number of days in cold waves varied from 11 to 35 , and the mean annual number of cold days - from 33 to 56 (Tab. 3).

Warm waves. The mean annual number of warm waves varied from approximately 2 in Tokyo to approximately 8 in Paris. The mean duration of the warm waves was from 3.3 to 4.8 days. Warm waves did not occur in all of the study years at all of the stations. The highest number of waves was observed at the New York-JFK station in 2006 (15 waves), and the highest number of days in waves occurred in 2010 at the same station (71 days). For the annual scale at the majority of the stations, the waves were usually recorded at the turn of spring and summer, and seldom recorded in autumn (which is different to the results obtained using the relative method). The mean annual number of days in warm waves varied from 9 to 36 , and the mean annual number of warm days - from 33 to 58. The lowest values occurred in Tokyo, and the highest in Paris (Tab. 3).

Wave duration. From 3 to 6 very short warm waves occurred, on the average, per year, as well as from 2 to 6 cold waves. There were up to 2 short waves, with less frequent occurrences of longer waves. It is also difficult to unequivocally determine the predomination of one type of waves. Short warm waves in Cape Town showed the most predominance.

\section{The relative method applying standard deviation - zone $\mathrm{D}$}

Cold waves. In zone $D$, the mean annual number of cold waves varied from approximately 14 in Stockholm to approximately 16 in Toronto (Tab. 4). Their mean duration

Table 3. Warm and cold waves in zone $\mathrm{C}$ calculated by means of the relative and arbitrary method (abbreviation 'm.' means mean wave duration, abbreviation 'meets cri.' means the number of all days meeting the criteria of the inequality included in the method)

\begin{tabular}{|c|c|c|c|c|c|c|c|c|c|c|}
\hline & & & \multicolumn{4}{|c|}{ Cold waves } & \multicolumn{4}{|c|}{ Warm waves } \\
\hline & & & \multicolumn{2}{|c|}{ relative method } & \multicolumn{2}{|c|}{ arbitrary method } & \multicolumn{2}{|c|}{ relative method } & \multicolumn{2}{|c|}{ arbitrary method } \\
\hline & & & & & & & & & & \\
\hline \multirow[t]{2}{*}{ Tokyo Intl } & \multicolumn{2}{|c|}{ m. 30 years } & 14.97 & 72.50 & 3.17 & 11.77 & 14.30 & 72.03 & 2.43 & 8.57 \\
\hline & $\mathrm{m}$. & meets cri. & 4.8 & 111.97 & 3.7 & 35.27 & 5.0 & 113.57 & 3.5 & 33.17 \\
\hline \multirow{2}{*}{$\begin{array}{l}\text { Shanghai- } \\
\text {-Hongqiao }\end{array}$} & \multicolumn{2}{|c|}{ m. 30 years } & 15.73 & 79.97 & 4.87 & 20.57 & 14.83 & 76.63 & 4.93 & 19.57 \\
\hline & $\mathrm{m}$. & meets cri. & 5.1 & 114.07 & 4.2 & 45.70 & 5.2 & 109.90 & 4.0 & 44.07 \\
\hline \multirow{2}{*}{$\begin{array}{l}\text { New } \\
\text { York-JFK }\end{array}$} & \multicolumn{2}{|c|}{ m. 30 years } & 16.47 & 76.53 & 6.70 & 28.40 & 14.73 & 73.60 & 6.43 & 28.43 \\
\hline & $\mathrm{m}$. & meets cri. & 4.7 & 112.33 & 4.2 & 53.90 & 5.0 & 110.50 & 4.4 & 55.40 \\
\hline \multirow{2}{*}{$\begin{array}{l}\text { London- } \\
\text {-Heathrow }\end{array}$} & \multicolumn{2}{|c|}{ m. 30 years } & 15.17 & 93.10 & 4.23 & 19.07 & 15.70 & 84.93 & 4.73 & 21.03 \\
\hline & $\mathrm{m}$. & meets cri. & 6.1 & 119.23 & 4.5 & 39.07 & 5.4 & 112.13 & 4.4 & 41.90 \\
\hline \multirow[t]{2}{*}{ Paris-Orly } & \multicolumn{2}{|c|}{ m. 30 years } & 16.00 & 97.97 & 7.00 & 35.07 & 15.07 & 87.57 & 7.63 & 36.40 \\
\hline & $\mathrm{m}$. & meets cri. & 6.1 & 119.53 & 5.0 & 55.67 & 5.8 & 112.33 & 4.8 & 57.97 \\
\hline \multirow[t]{2}{*}{ Sydney } & \multicolumn{2}{|c|}{ m. 30 years } & 16.50 & 75.60 & 3.03 & 10.63 & 13.73 & 59.33 & 2.80 & 9.33 \\
\hline & $\mathrm{m}$. & meets cri. & 4.6 & 116.57 & 3.5 & 33.60 & 4.3 & 103.93 & 3.3 & 39.60 \\
\hline \multirow[t]{2}{*}{ Istanbul } & \multicolumn{2}{|c|}{ m. 30 years } & 14.17 & 92.87 & 6.37 & 27.50 & 14.50 & 88.27 & 6.03 & 25.60 \\
\hline & $\mathrm{m}$. & meets cri. & 6.6 & 112.77 & 4.3 & 46.13 & 6.1 & 111.47 & 4.3 & 47.47 \\
\hline \multirow{2}{*}{$\begin{array}{l}\text { Cape } \\
\text { Town }\end{array}$} & \multicolumn{2}{|c|}{ m. 30 years } & 16.20 & 73.63 & 3.17 & 11.47 & 12.87 & 55.43 & 6.93 & 25.43 \\
\hline & $\mathrm{m}$. & meets cri. & 4.6 & 111.93 & 3.6 & 32.63 & 4.3 & 98.47 & 3.7 & 52.00 \\
\hline
\end{tabular}


was from 5.0 to 6.2 days. The waves occurred in all of the study years, and the number of waves decreased. They were recorded the most frequently in the warm half-year, except for the station in Moscow, where the waves were the most frequent in February. The cold waves were observed somewhat less often in the cold half-year. The lowest number of waves was recorded in 1987 in Toronto (7 waves), and the highest at the Stockholm-Bromma station in 1985 (25 waves). In the case of days in cold waves, the lowest values occurred in 1987 in Toronto (35 days), and the highest in 1985 at the Stockholm- occurred in all of the study years. The lowest number of waves was observed in 1985 (4 waves), and the highest in 1999 (24 waves). Both of the values were recorded in Stockholm. The lowest number of days in waves was observed in 1985 at the Stockholm-Bromma station (20 days), and the highest at the same station in 1999 (158 days). The number of days in warm waves in this zone averaged from 84 to 99 days annually, and the number of warm days - from 114 to 120 days annually (Tab. 4). In this zone, 4 extremely long warm waves were observed - 3 waves in Stockholm and 1 wave in Moscow.

Table 4. Warm and cold waves in zone D calculated by means of the relative and arbitrary methods (abbreviation 'm.' means mean wave duration, abbreviation 'meets cri.' means the number of all days meeting the criterion of inequality in the formula included in the method)

\begin{tabular}{|c|c|c|c|c|c|c|c|c|c|c|}
\hline & & & \multicolumn{4}{|c|}{ Cold waves } & \multicolumn{4}{|c|}{ Warm waves } \\
\hline & & & relative & method & arbitrary & $y$ method & relative & method & arbitrary & $y$ method \\
\hline \multicolumn{3}{|c|}{ Zone D } & $\begin{array}{c}\text { no. } \\
\text { of waves } \\
\text { /year }\end{array}$ & $\begin{array}{c}\text { no. } \\
\text { of days } \\
\text { in waves } \\
\text { year }\end{array}$ & $\begin{array}{c}\text { no. waves } \\
\text { /year }\end{array}$ & $\begin{array}{c}\text { no. } \\
\text { of days } \\
\text { in waves } \\
\text { year }\end{array}$ & $\begin{array}{c}\text { no. waves } \\
\text { /year }\end{array}$ & $\begin{array}{c}\text { no. } \\
\text { of days } \\
\text { in waves } \\
\text { year }\end{array}$ & $\begin{array}{c}\text { no. waves } \\
\text { /year }\end{array}$ & $\begin{array}{c}\text { no. } \\
\text { of days } \\
\text { in waves } \\
\text { year }\end{array}$ \\
\hline \multirow{2}{*}{$\begin{array}{l}\text { Stockholm- } \\
\text {-Bromma }\end{array}$} & \multicolumn{2}{|c|}{ m. 30 years } & 14.40 & 89.20 & 5.90 & 27.50 & 4.180 & 91.43 & 6.97 & 34.53 \\
\hline & & meets cri. & 6.2 & 113.73 & 4.7 & 49.63 & 6.2 & 113.87 & 5.0 & 53.87 \\
\hline \multirow[t]{2}{*}{ Toronto } & \multicolumn{2}{|c|}{ m. 30 years } & 15.93 & 79.63 & 6.20 & 25.10 & 15.63 & 83.50 & 6.57 & 29.30 \\
\hline & $\mathrm{m}$. & meets cri. & 5.0 & 111.73 & 4.1 & 51.60 & 5.3 & 115.70 & 4.5 & 53.70 \\
\hline \multirow{2}{*}{$\begin{array}{l}\text { Moscow- } \\
\text {-Sheremet. }\end{array}$} & \multicolumn{2}{|c|}{ m. 30 years } & 15.50 & 92.27 & 10.23 & 50.90 & 15.37 & 99.07 & 10.13 & 55.73 \\
\hline & $\mathrm{m}$. & meets cri. & 6.0 & 113.50 & 5.0 & 7467 & 6.5 & 119.60 & 5.5 & 79.50 \\
\hline
\end{tabular}

-Bromma station (192 days). The mean annual number of days in cold waves in this zone varied from 80 in Toronto to 92 in Moscow (Tab. 4). A lower variability occurred in the case of the number of cold days, ranging from 112 to 114 days annually, on the average. Over the study years in Stockholm, one very long cold wave occurred, lasting for 35 days.

Warm waves. The mean annual number of warm waves varied from approximately 15 in Stockholm to approximately 16 in Toronto. Their mean duration was from 5.3 to 6.5 days. They were the most frequently recorded in the cold half-year, and more seldom in the warm half-year. The waves
Wave duration. In the study period, cold waves predominated over warm waves. From 8 to 12 cold waves, and from 8 to 11 warm waves, on the average, occurred annually in the case of very short waves, as well as approximately four short waves of both types, and one moderately long wave. Longer waves occurred less than once per year. The largest differences were observed in Toronto in the case of waves with a duration of 3-5 days in favour of cold waves, and in favour of warm waves in the case of waves with a duration of 6-10 days. 


\section{The arbitrary method used for applying a threshold of $4^{\circ} \mathrm{C}$ - zone D}

Cold waves. In zone $D$, the mean annual number of cold waves varied from approximately 6 in Stockholm to approximately 10 in Moscow. The waves had a mean duration of from 4.1 to 5.1 days. Cold waves occurred at all of the stations in all of the study years. The lowest number of waves was recorded in 2006 at the Stockholm-Bromma station, and in 1998 in Toronto (1 wave), and the highest at the Moscow-Sheremetyevo station in 1993 (17 waves). The number of days in cold waves varied from 3 (Toronto - 2006) to 96 (Moscow-Sheremetyevo - 1993). In the course of the year, the waves were the most frequent in winter. There were seldom cold waves in summer. The mean annual number of days in cold waves was from 25 to 51 , and the mean annual number of cold days - from 50 to 75 (Tab. 4).

Warm waves. The mean annual number of warm waves in the zone varied from approximately 7 in Toronto and Stockholm to approximately 10 in Moscow. Their mean duration was from 4.5 to 5.6 days. Warm waves occurred at all of the stations in all of the study years. The lowest number of waves was recorded in 1987 at the Stockholm-Bromma station and in 1993 in Toronto (1 wave), and the highest at the Moscow-Sheremetyevo station in 1989 (19 waves). The number of days in warm waves varied from 4 (Toronto, 1993) to 105 (Moscow-Sheremetyevo, 2010). The waves were usually recorded in winter, and more seldom in late summer and autumn (which means that winters are getting warmer, so this $4^{\circ} \mathrm{C}$ threshold is exceeded more often). The mean annual number of days in warm waves varied from 29 to 56, and the mean annual number of warm days - from 54 to 80 . The highest values occurred in Moscow (Tab. 4). During the 1981-2010 time period, one very long thermal wave was observed - it was a warm wave in Moscow, and this wave had a duration of 46 days.
Wave duration. From 4 to 8 very short cold waves, and from 5 to 7 very short warm waves occurred annually, on the average. Short waves were recorded from 1 to 3 times per year, and longer waves were observed less than once per year. In the study period, warm waves generally prevailed, with the highest dominance of very short cold waves in Moscow.

\section{Discussion}

Both of the methodological approaches analysed in the paper have their advantages, although they also present certain significant limitations.

On the one hand, in practice, relative methods boil down to the assumption of a certain percent of days in a study period described as 'warm', and (at symmetrical distributions) a similar percent of days described as 'cold'. Should several of such days occur in a sequence, they are collectively referred to as a wave. As a result, one example is the number of warm waves and their mean duration in Istanbul in zone $\mathrm{C}$ which is very similar to the number and mean duration of warm waves in Stockholm in zone D (Tabs. 3 and 4).

On the other hand, it is a generally known fact that the temperature sensations of living organisms change from warm towards colder climates, and extreme temperature values in any climate are perceived as 'warm' or 'cold', as reflected by the relative methods. Especially harmful for living organisms are extreme heatwaves, like the 2003 European heatwave. Such heatwaves causes deaths, especially among the elderly. To prevent such an impact, an early warning system was established in Europe, called EuroHEAT. Cold waves can cause even more deaths than heat (from heart and respiratory diseases and strokes), but cold waves do not receive as much attention in the media as heatwaves (EC 2015).

In the arbitrary method, it is assumed that when the difference between the mean multiannual temperature value and the temperature recorded on a given day exceeds 
$4^{\circ} \mathrm{C}$, such a day is described as warm or cold. A sequence of several such days (warm or cold) are referred to as a wave. As a result, in climates distinguished by low thermal variability (zones $A$ and $B)^{3}$, this method shows no waves. The higher the weather variability, the more thermal waves are observed. Results obtained by means of this method reflect the climatic distinctness of studied stations very well, showing high differences between zones.

The adopted threshold of $4^{\circ} \mathrm{C}$ is a questionable issue. The authors do not justify the application of this specific value. It is worth considering increasing the threshold to e.g. $5^{\circ} \mathrm{C}$ to focus on strong thermal waves, more unfavourable for living organisms.

Temperature (maximum, minimum, or mean) applied by a given method is a very important element in the analysis of thermal waves. As accurately mentioned by Wibig (2007), in the case of the identification of waves based on maximum temperature - the waves constitute sequences of warm and cold days, and in the case of minimum temperature - a sequence of warm and cold nights. It is problematic that minimum and maximum temperatures reflect a 'momentary' (the highest or lowest) temperature value during a day. It is worth considering the identification of thermal waves based on mean daily temperatures, like in the case of the relative method presented in the paper.

\section{Summary}

This paper compares two methods of identification of warm and cold waves, representing two methodologically different approaches: the relative method, applying the standard deviation, and the arbitrary method, using the determined difference in temperatures.

- The relative method permitted the identification of more warm and cold waves in both of the study zones (with an annual

\footnotetext{
3 Zones $A$ and $B$ were excluded from this comparison, because there were few or no thermal waves observed.
}

mean of approximately a dozen waves) than the arbitrary method (with an annual mean of a maximum of ten waves).

- The relative method also permitted the identification of more days in waves (annual mean from approximately 70 to almost 100 days), and more warm and cold days (averaging approximately 110 -120) than the arbitrary method (annual mean of approximately 10-50 days in waves and 30-80 warm and cold days, respectively).

- Warm and cold waves calculated by means of the relative method are longer (averaging approximately 5-7 days) than those calculated by means of the arbitrary method (averaging approximately 3-5 days).

- The number of warm and cold waves determined by means of the relative method in the 1981-2010 time period was varied, and ranged from several to almost thirty waves annually at the study stations.

- The number of warm and cold waves determined by means of the arbitrary method in the 1981-2010 time period varied from only a few to a over dozen waves annually at the study stations. This method shows a lower variability of particular wave parameters than the relative method.

- In the study period which covered thirty years (1981-2010), cold waves (and the analysed parameters of cold waves such as: number of days in waves, number of cold days, and duration of cold waves) prevailed over warm waves (and their analysed parameters). Nonetheless, the number of cold waves decreased, and that of warm waves increased, which is in accordance with the current studies (Morawska-Horawska 1991; Mager \& Kuźnicka-Błaszczyńska 1993; Miętus \& Filipiak 2001; Balafoutis \& Arseni-Papadimitriou 2002; Owczarek 2008).

- The analysed parameters of warm and cold waves determined by means of the relative method, show low variability at all of the stations in the studied climatic zones. The arbitrary method showed larger 
differences between zones and subzones - the wave parameters (number of waves, wave duration, and number of warm and cold days) increased towards colder climates.

\section{References}

Balafoutis C., Arseni-Papadimitriou A., 2002. Lengths of very warm and very cold spells at southern Balkans [in:] G. Wójcik, K. Marciniak (eds.), Działalność naukowa Profesora Władysława Gorczyńskiego i jej kontynuacja, Sympozjum Klimatologiczne na Uniwersytecie Mikołaja Kopernika, Toruń, 16-17 IX 1993, Lublin: Wydawnictwo UMK, pp. 155-162.

Degirmendžıć J., 1999. Fale termiczne w Europie zwiqzane z wpływem klinów Wyżu Azjatyckiego [in:] J. Jakóbczyk-Gryszkiewicz, K. Kłysik (eds), Nauki geograficzne a edukacja społeczeństwa: Materiały XLVIII Zjazdu Polskiego Towarzystwa Geograficznego. Łódź, 9-11 września 1999 r. T. 1. Problemy nauczania, Łódź: Polskie Towarzystwo Geograficzne, Uniwersytet Łódzki, pp. 146-149.

Degirmendžlć J., 2004. Fale termiczne nad Polska w zimie w zależności od pola wiatru w Europie. Przegląd Geofizyczny, vol. 49, no. 1-2, pp. 11-23.

EC, 2014. Public health responses to heat waves. European Commission, http://ec.europa.eu/ health/climate_change/extreme_weather/ heatwaves/index_en.htm [16 June 2015].

Koppe C., Kovats S., Jendritzky G., Menne B., 2004, Heat-Waves: Risks and Responses. WHO Series, vol. 2, Copenhagen: Health and Global Environmental Change.

Kossowska-Cezak U., Twardosz R., 2012a. Niezwykle gorqce miesiace i sezony letnie w Europie Środkowej i Wschodniej (1951-2010). Cz. I niezwykle gorace miesiace letnie. Przegląd Geofizyczny, vol. 57, no. 3-4, pp. 299-324.

Kossowska-Cezak U., Twardosz R., 2012b. Niezwykle gorqce miesiace i sezony letnie w Europie Środkowej i Wschodniej(1951-2010). Cz. II niezwykle gorace sezony letnie. Przeglad Geofizyczny, vol. 57, no. 3-4, pp. 325-342.

Kottek, M., Grieser J., Beck C., Rudolf B., Rubel F., 2006. World Map of the Köppen-Gei-
Editors' note:

Unless otherwise stated, the sources of tables and figures are the authors' on the basis of their own research.

ger climate classification updated. Meteorologische Zeitschrift, vol. 15, no. 3, pp. 259-263.

Kozłowska-Szczęsna T., Krawczyk B., KuchCIK M., 2004, Wpływ środowiska atmosferycznego na zdrowie i samopoczucie człowieka. Monografie IGiPZ PAN, vol. 4, Warszawa: Instytut Geografii i Przestrzennego Zagospodarowania PAN.

KRZYŻEWSKA A., 2007. Dane internetowe NCDC a dane pomiarowe IMGW - porównanie na przykładzie stacji Lublin-Radawiec (19951999) [in:] M. Miętus, J. Filipiak, A. Wyszkowski (eds.), 200 lat regularnych pomiarów i obserwacji w Gdańsku, Warszawa: Instytut Meteorologii i Gospodarki Wodnej, pp. 135-145.

KrzYŻEWSKA A., 2010. Fale upałów jako zjawisko ograniczajace turystykę $w$ duzych miastach świata [in:] A. Richling (ed.), Krajobrazy rekreacyjne - kształtowanie, wykorzystanie, transformacja, Problemy Ekologii Krajobrazu, vol. 27, pp. 239-244.

KrzYŻewSka A., Wereski S., 2011. Fale upałów i mrozów w wybranych stacjach Polski na tle regionów bioklimatycznych (2000-2010). Przegląd Geofizyczny, vol. 56, no. 1-2, pp. 99-109.

KUCHCIK M., 2006. Defining heat waves - different approaches. Geographia Polonica, vol. 79, no. 2, pp. 47-63.

KYSELÝ J., 2010. Recent severe heat waves in central Europe: how to view them in a long term prospect? International Journal of Climatology, vol. 30, no. 1, pp. 89-109.

Mager P., Kuźnicka-BŁaszczyŃsKa M., 1993. Wybrane parametry fal chłodu i ciepła w Poznaniu w latach 1911-1990 [in:] K. Kożuchowski (ed.), Globalne ocieplenie a współczesne zmiany klimatyczne w Polsce, Szczecin: Wydawnictwo Naukowe Uniwersytetu Szczecińskiego, pp. 277-288.

Matthes H., Rinke A., Dethloff K., 2009. Variability of observed temperature-derived 
climate indices in the Arctic. Global and Planetary Change, vol. 69, no. 4, pp. 214-224.

Matzarakis A., Nastos P.T., 2010. HumanBiometeorological assessment of heat waves in Athens. Theoretical and Applied Climatology, vol. 105, no. 1, pp. 99-106.

Miętus M., Filipiak J., 2001. Struktura czasowo-przestrzennej zmienności warunków termicznych w rejonie Zatoki Gdańskiej. Warszawa: Instytut Meteorologii i Gospodarki Wodnej.

MoraWSKa-HorawSKa M., 1991. Fale ciepła i chłodu w Krakowie w stuleciu 1881-1980. Wiadomości IMGW, vol. 14, no. 1-4, pp. 127-136.

Nastos P.T., Kapsomenakis J., 2014. Regional climate model simulations of extreme air temperature in Greece. Abnormal or common records in the future climate? Atmospheric Research, vol. 152, no. 1, pp. 43-60.

Niedźwiedź T., 2003. Słownik meteorologiczny. Warszawa: Instytut Meteorologii i Gospodarki Wodnej.

NCDC, 2014. Global Summary of the Day, National Climatic Data Center, http://www7. ncdc.noaa.gov/CDO/cdo [5 December 2014].

Nghiem S.V. Balk D., Rodriguez E., Neumann G., Sorichetta A., Small C., Elvidge C.D., 2009. Observations of urban and suburban environments with global satellite scatterometer data. ISPRS Journal of Photogrammetry and Remote Sensing, vol. 64, no. 4, pp. 367-380.

OwczArek M., 2008. Zmienność warunków termicznych na Pomorzu na przykładzie fal ciepła i chłodu, 1951-2005 [in:] K. Kłysik, J. Wibig, K. Fortuniak (eds.), Klimat i bioklimat miast, Łódź: Wydawnictwo Uniwersytetu Łódzkiego, pp. 199-208.
ÖZDOĞAN M., 2011. Modelling the impacts of climate change on wheat yields in Northwestern Turkey. Agriculture, Ecosystems and Environment, vol. 141, no. 1-2, pp. 1-12.

RoBINSON P., 2001. On the definition of a heat wave. Journal of Applied Meteorology, vol. 40, no. 4, pp. 762-775.

StOPA-BoryczKa M., BoryczKa J., KossowsKa-Cezak U., Wawer J., 2011. Fale chłodu i ciepła $w$ przebiegu rocznym temperatury powietrza w Warszawie (1951-2010). Przegląd Geofizyczny, vol. 56, no. 3-4, pp. 181-200.

WIBIG J., 2007. Fale ciepła i chłodu w środkowej Polsce na przykładzie Łodzi. Acta Universitatis Lodziensis, Folia Geographica Physica, vol. 8, pp. 27-61.

Wibig J., Podstawczyńska A., Rzepa M., PiotrowSKI P., 2009a. Coldwaves in Poland - frequency, trends and relationships with atmospheric circulation. Geographia Polonica, vol. 82, no. 1, pp. 47-59.

Wibig J., Podstawczyńska A., Rzepa M., PiotrowSKI P., 2009b. Heatwaves in Poland - frequency, trends and relationships with atmospheric circulation. Geographia Polonica, vol. 82, no. 1, pp. 33-46.

WMO, 1992. International meteorological vocabulary. WMO, no. 182, Geneva: World Meteorological Organization.

YANG Y., WILSON L.T., Wang J., 2010. Development of an automated climatic data scraping, filtering and display system. Computers and Electronics in Agriculture, vol. 71, no. 1, pp. 77-87. 
http://rcin.org.pl 